\title{
八ロセン麻酔中の血漿カテコラミン 濃度に関する実験的研究
}

岡山大学歯学部口腔外科学第 1 講座（主任：西嶋克巳教授)

矢尾尚武

(昭和59年 5 月 7 日受稿)

\author{
Key words : ハロセン, エピネフリン, \\ ノルエピネフリン, \\ ガスクロマトグラフ, \\ 高速液体クロマトグラフ
}

緒言

ノルエピネフリン (NE) およU゙エピネフリン

(E) は, 神経組織中に含まれるカテコラミン (CA)

で, 神経伝達物質 (neurotransmitter) である゙1.

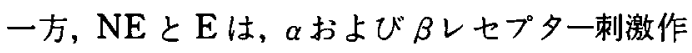

用を持ち, 循環器系への影響があることが知られ れている2)。

$\mathrm{NE}$ は，ほとんどが交感神経終末より放出さ れ，大部分は，再び終末に取り込まれるが，一 部は, 血液中へ放出される。また, 交感神経の 活動に伴い, 副腎娟質からも $\mathrm{NE} \mathrm{E}$ が血液中 に放出される゙．したがって，血漿 CA 濃度を測 定することは，交感神経の活動を推定する上の 一つの指標となる4).

$\mathrm{CA}$ は， $\alpha$ およU゙ $\beta$ レプタ一刺激作用を有す るために, 麻酔薬の循環器系への作用を検討す る際には，血漿 $\mathrm{CA}$ 濃度の測定は，重要な意義 を有する。

八ロセンは, 血䪹 $\mathrm{CA}$ 濃度を減少させるとい

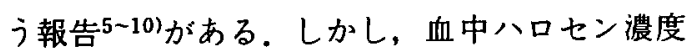
と血漿 CA 浱度の関係を検討した報告はない。

本研究は，八ロセン吸入開始から60分後まで, さらにハロセン麻醉 60 分後に電気刺激を与えて 30 秒後と 5 分後の血中八ロセン濃度と血漿 CA 濃度を測定し, 血中八口セン濃度と血漿 $\mathrm{CA}$ 濃 度の動態と，その関係について検討した。
方

法

奏験は、雑種成犬（体重 8－15 kg）を用い, 八ロセン $1 \%$ 吸入群と $2 \%$ 吸入群についてそれ ぞれ 6 頭づつ行った。

まず，動物は，塩酸ケタミンと硫酸アトロピ ンの筋注により麻酔を行い，図1のごとく前肢 静脈に静脈路をとり，乳酸加リンゲル液を輸液 ( $5 \sim 10 \mathrm{ml} / \mathrm{kg} / \mathrm{hour})$ するとともに，血圧およ

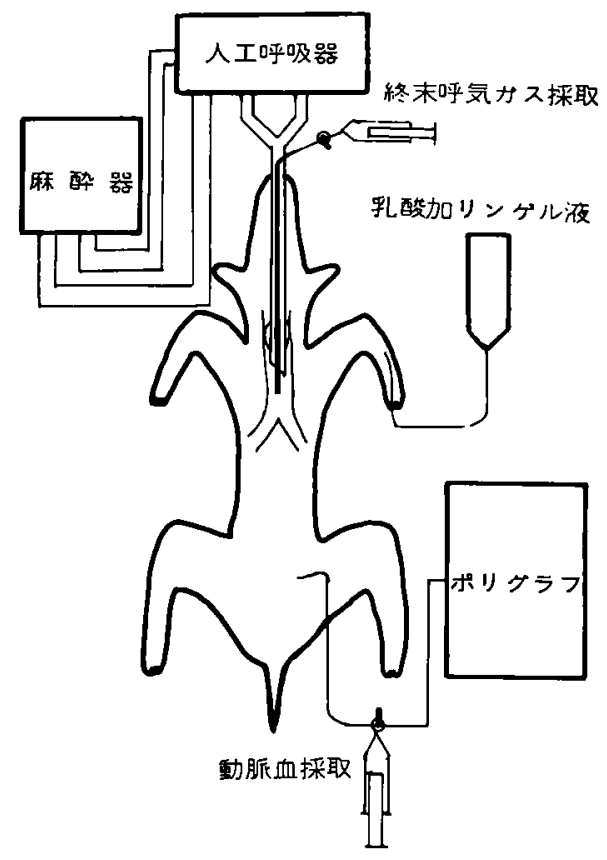

図 1 奏験の奏際図 
び心拍数の測定と採血用に大腿動脈にカテーテ ルを挿入した，次に，動物は，静脈路よりパン クロニウム投与により非動化した㣪挑管し，純 酸素による人工呼吸 $\left(\mathrm{PaCO}_{2} 30\right.$ ４0 torr $)$ を行 った，麻酔回路は，半閉鎖開路を用い，人工呼 吸器は、 Oxford ventilator 小児用(ペンロン社 製), 麻酔菂気化器は, Fluotec 3 (サイプレン 社製）を用いた。

測定項目は，血圧，心拍数のほか，終末呼気 中八ロセン濃度, 血中八ロセン濃度, 血漿 CA 濃度と換気状態を一定とするため，血液がスを 測定した。

八ロセンの投与は，血圧と心拍数が挿管前と 同様になった時点，すなわち，塩酸ヶタミンの 影響がなくなった時点より行った。

血圧，心拍数，血漿 CA 濃度の对照は，挿管 5 分後とし，採血は，挿管 5 分後，八口セン吸 入開始より $5 ， 10,15,30,45 お よ ひ ゙ 60$ 分後に 行い，血圧，心拍数，血中八ロセン濃度および 血漿 CA 濃度および血液がスを測定した。

また，終末呼気中八口セン濃度は，八口セ ン吸入開始から 1 分毎に終末呼気がスを採取し 測定した。終末呼気がスの採取は，気管内挿管 チューブのスリップジョイント側に小孔を開け，

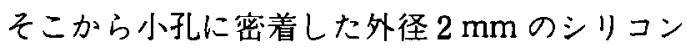
チューブを気管分岐部まで挿入するとともに， 採取する端は，三方活栓をつけてガラス注射筒 を用いて行った。

さらに，八ロセン吸入開始から60分後には， $100 \mathrm{~V}, 1$ 回/秒の刺激を 10 回右上顎犬歯に与之, 刺激終了後 30 秒後およU゙ 5 分後に血圧，心拍数 を測定するとともに，採血，終末呼気がスの採 取を行い，血液がス，血中八ロセン濃度，血漿 CA 濃度および終末呼気中八ロセン濃度を測 定した。

血圧および心拍数は，日本光電製ポリグラフ， Polygraph system RM 6000型を用い, 電気刺 激は, 日本光電彆 Electronic stimulator SEN7103型を用いた。

血液ガスは,ラジオメー夕社製 BMS $3 \mathrm{M} \mathrm{K} 2$ 型血液ガス分析装置を用い, $\mathrm{pH}, \mathrm{PaCO}_{2}, \mathrm{PaO}_{2}$ を測定した。

血中八ロセン濃度の測定は, 山田ら $(1982)^{11)}$
表 1 終末呼気中ハロセン分析条件

Carrier :

Flow $\quad 1.2\left(\mathrm{~N}_{2}\right) \quad 0.6 \mathrm{~kg} / \mathrm{cm}^{2}$

Column:

Column temprature $120^{\circ} \mathrm{C}$

Molecular sieve-5 A

60-80 mesh

S.U.S. L $1.0 \mathrm{~m}$, I.D. $3 \mathrm{~mm}$

Detector :

FID

$\mathrm{H}_{2}$ flow $0.8 \mathrm{~kg} / \mathrm{cm}^{2}$

Air flow $1.0 \mathrm{~kg} / \mathrm{cm}^{2}$

Sensitivity $10 \mathrm{M} \Omega$

Range $\quad 1.28 \mathrm{~V}$

使用ガスクロマトグラフ：

島津 $\mathrm{GC} 3 \mathrm{BF}$

表 2 高速液体クロマトグラフの分析条件

Carrier :

$5 \mathrm{mM}$ Citric acid $0.8 \mathrm{ml} / \mathrm{min}$

$2.5 \mathrm{mM}$ sodium citrate

Column :

Nucleosil-5 SA, $40^{\circ} \mathrm{C}$

Reaction : THI Method

I . $0.1 \mathrm{M}$ potasium phosphate, monobasic $0.1 \mathrm{M}$ potasium phosphate, dibasic $0.1 \%$ fericyanide

II . $0.05 \%$ ascorbic acid $0.05 \%$ sodium metabisulfite

III. $4 \mathrm{~N}-\mathrm{NaOH}$

Detector :

Fluorescence

Spectoromonitor (島津 510-A)

使用液体クロマトグラフ：

島津 LC-3 A

のガスクロマトグラフ法を用い，終末呼気中 八ロセン濃度の測定は，表 1 の条件によりガス クロマトグラフを用いた。

血漿 $\mathrm{CA}$ 濃度の测定は，表 2 の条件により， 高速液体クロマトグラフ (島津製 LC-3A 型)を 用い，THI法 ${ }^{12,13)} に よ り$ 行った。また，血漿 CA 濃度の測定の試料の前処理は, 図 2 に示すよj に扇谷ら $(1982)^{14)}$ の方法を改良し,メタノール 
による洗浄，吸引乾燥を行い，高精度の方法を 考案した。

データは, student $\mathrm{t}$ testにより推計学的に 有意の差を検討した。

\section{結 果}

血圧：ハロセン吸入に伴う血圧の変化は，表

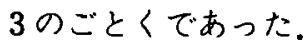

$1 \%$ 吸入群の収縮期血圧は，対照と比較して 八ロセン吸入開始 5 分以後は，有意 $(p<0.01)$ に減少した。また，拡張期血圧は，八口セン吸 入開始 10 分以後，有意 $(p<0.01)$ に減少した。

$2 \%$ 吸入群の収維期血圧は，対照と比較して 八口セン吸入開始 5 分以後は, 有意 $(p<0.01)$ に減少した，また，拡張期血圧は，八ロセン吸 入開始 5 分後には， $\mathrm{p}<0.05$ で，10分以後には， $\mathrm{p}<0.01$ で有意に減少した。

1.

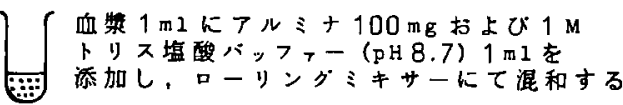

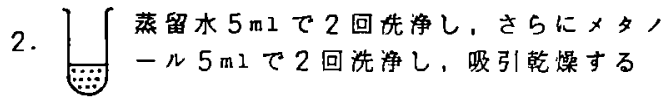

3. ] $0.4 \mathrm{~N}$ 酸 $0.3 \mathrm{ml}$ 添加し，ローリング ミキキーにーに混和する

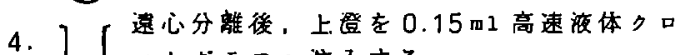
○トグラフへ注入する

図 2 試料の前処理
また， $1 \%$ 吸入群と $2 \%$ 吸入群のそれぞれの 血圧を比較すると $2 \%$ 吸入群の方が，収縮期血 压は，八口セン吸入開始45分，60分後，刺激30 秒後および刺激 5 分後に有意 $(\mathrm{p}<0.05)$ に減 少した。また，拡張期血圧は，45分，60分後お よび刺激 30 秒後には，有意 $(\mathrm{p}<0.01)$ に減少 した。

心拍数：ハロセン吸入に伴う心拍数の変化は, 表 4 のごとくであった。

$1 \%$ 吸入群は，对照と比較してハロセン吸入 開始30分以後は，有意 $(p<0.05)$ に減少した。 $2 \%$ 吸入群は，对照と比較してハ口セン吸入 開始45分以後は，有意 $(p<0.01)$ に減少した。 また， $1 \%$ 吸入群と $2 \%$ 吸入群を比較すると， すべての時点において有意差は認められなかっ た。

終末呼気中八ロセン濃度: 終末呼気中八口 セン濃度は，表 5 ，図 3 のごとくであった。

$1 \%$ 吸入群，2\%吸入群ともに，八ロセン吸 入開始15分後まで急速に増加し，30分以後は, 増加傾向が少なくなり，ほぼ一定の濃度の排出 が認められた。

また， $1 \%$ 吸入群と $2 \%$ 吸入群とを比較する と， $2 \%$ 吸入群の方が，八ロセン吸入開始 5 分 以後, 終末呼気中八口セン濃度の有意 $(p<0.01)$ の増加が認められた。

血中八ロセン濃度：血中八ロセン濃度の変化 は，表 6 ，図 4 のごとくであった。

表 3 八ロセン吸入に伴う血圧の経時的変化

\begin{tabular}{|c|c|c|c|c|c|c|c|c|c|c|}
\hline & & 対照任 & 5 分 & 10 分 & 15 分 & 30 分 & 45 分 & 60 分 & 刺解 30 秒 & 制散 5 分 \\
\hline \multirow{3}{*}{$1 \%$ 吸入群 } & & & & & & & 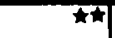 & $\star \star 1$ & & \\
\hline & 収樎期血压 & $194 \pm 16$ & $160 \pm 7$ & $146 \pm 10$ & $140 \pm 12$ & $126 \pm 25$ & $126+24$ & $124 \pm 21$ & $123+16$ & $119+25$ \\
\hline & 应張期血圧 & $129 \pm 20$ & $107 \pm 16^{\star \star}$ & $95+16^{\star x}$ & $93+11^{\star * A}$ & $82+13$ & $79 \pm 13$ & $79 \pm 10^{\star \star}$ & $81 \pm 8$ & $74 \pm 15$ \\
\hline & & & $\star \star$ & $\star \star$ & $\star \star \star \Delta$ & $\hbar \star$ & th & $\hbar$ & $\star x$ & 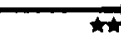 \\
\hline \multirow{3}{*}{$2 \%$ 吸入群 } & 収樎䐓血压 & $186 \pm 22$ & $137 \pm 32$ & $124 \pm 26$ & $121 \pm 22$ & $102+16$ & $90+20$ & $86 \pm 25$ & $92+18$ & $90+19$ \\
\hline & & & & & 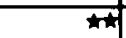 & 車 & the & Wh & $\neq \neq$ & $\hbar \star$ \\
\hline & 搪張期血压 & $123 \pm 15$ & $91 \pm 31$ & $75 \pm 19$ & $79 \pm 17$ & $66 \pm 16$ & $56 \pm 13$ & $53+17$ & $58 \pm 16$ & $55 \pm 15$ \\
\hline
\end{tabular}

两群ともに $\mathrm{n}=6$ ，策位: $\mathrm{mmHg}$, Mean $+\mathrm{SD}$,

*P<0.05，**P<0.01 (対炤と比接して) 
表 4 八ロセン吸入に伴う心拍数の経時的変化

\begin{tabular}{|c|c|c|c|c|c|c|c|c|c|}
\hline & 対照 位 & 5 分 & 10 分 & 15 分 & 30 分 & 45 分 & 60 分 & 刺激 30 秒 & 刺潵 5 分 \\
\hline 1\%吸入群 & $\begin{array}{r}173 \\
+42\end{array}$ & $\begin{array}{r}177 \\
+34\end{array}$ & $\begin{array}{r}158 \\
+30\end{array}$ & $\begin{array}{r}150 \\
\pm 18\end{array}$ & $\begin{array}{l}126 \\
\pm 15\end{array}$ & $\begin{array}{l}120 \\
\pm 16\end{array}$ & $\begin{array}{l}121 \\
\pm 17\end{array}$ & $\begin{array}{l}123^{\star} \\
\pm 17\end{array}$ & $\begin{array}{l}121 \\
+19\end{array}$ \\
\hline 2\%吸入群 & $\begin{array}{r}163 \\
+29\end{array}$ & $\begin{array}{r}190 \\
+37\end{array}$ & $\begin{array}{r}172 \\
+34\end{array}$ & $\begin{array}{r}160 \\
+32\end{array}$ & $\begin{array}{r}136 \\
\pm 15\end{array}$ & $\begin{array}{l}116^{t} \\
\pm 9\end{array}$ & $\begin{array}{l}114^{-x} \\
\pm 3\end{array}$ & $\begin{array}{l}116^{7} \\
\pm 5\end{array}$ & $\begin{array}{l}116^{\text {th }} \\
\pm 7\end{array}$ \\
\hline
\end{tabular}

西群ともに $n=6$ ，筆位：拍 $/$ 分，Mean $\pm S D$,

* $P<0.05$, ** $P<0.01$ (対用と比较して)

表 5 八ロセン吸入に伴う終末呼気中ハロセン濃度の経時的変化

\begin{tabular}{|c|c|c|c|c|c|c|c|c|}
\hline & 5 分 & 10 分 & 15 分 & 30 分 & 45 分 & 60 分 & 刺激 30 秒 & 刺湤 5 分 \\
\hline $1 \%$ 吸入群 & $\begin{array}{r}0.34 \\
\pm 0.08\end{array}$ & $\begin{array}{r}0.45 \\
\pm 0.07\end{array}$ & $\begin{array}{r}0.51 \\
\pm 0.06\end{array}$ & $\begin{array}{r}0.62 \\
\pm 0.05\end{array}$ & $\begin{array}{r}0.65 \\
\pm 0.08\end{array}$ & $\begin{array}{r}0.69 \\
\pm 0.07\end{array}$ & $\begin{array}{r}0.69 \\
\pm 0.07\end{array}$ & $\begin{array}{r}0.71 \\
\pm 0.05\end{array}$ \\
\hline $2 \%$ 吸入群 & $\begin{array}{r}0.74 \\
\pm 0.33\end{array}$ & $\begin{array}{r}0.96 \\
\pm 0.21\end{array}$ & $\begin{array}{r}1.12 \\
\pm 0.19\end{array}$ & $\begin{array}{r}1.34 \\
\pm 0.18\end{array}$ & $\begin{array}{r}1.45 \\
\pm 0.19\end{array}$ & $\begin{array}{r}1.50 \\
\pm 0.14\end{array}$ & $\begin{array}{r}1.50 \\
\pm 0.16\end{array}$ & $\begin{array}{r}1.57 \\
\pm 0.13\end{array}$ \\
\hline
\end{tabular}

两群ともに $n=6$ ，单位 :\%。 Mean $\pm S D$,

表 6 八ロセン吸入に伴う血中ハロセン濃度の経時的変化

\begin{tabular}{|c|c|c|c|c|c|c|c|c|}
\hline & 5 分 & 10 分 & 15 分 & 30 分 & 45 分 & 60 分 & 籼激 30 秒 & 刺激 5 分 \\
\hline $1 \%$ 吸入群 & $4.6 \pm 1.1$ & $6.2 \pm 1.2$ & $7.2 \pm 1.7$ & $8.5 \pm 2.6$ & $9.3 \pm 2.7$ & $9.5 \pm 2.3$ & $10.0 \pm 2.6$ & $9.9 \pm 2.1$ \\
\hline $2 \%$ 吸入群 & $10.9 \pm 3.3$ & $15.3 \pm 3.0$ & $16.1 \pm 2.7$ & $20.0 \pm 4.2$ & $19.9 \pm 4.9$ & $21.9 \pm 5.0$ & $21.7 \pm 5.6$ & $22.4 \pm 5.5$ \\
\hline
\end{tabular}

両群ともに $n=6$, 単位 $: m g / d l$ blood, Mean \pm SD,

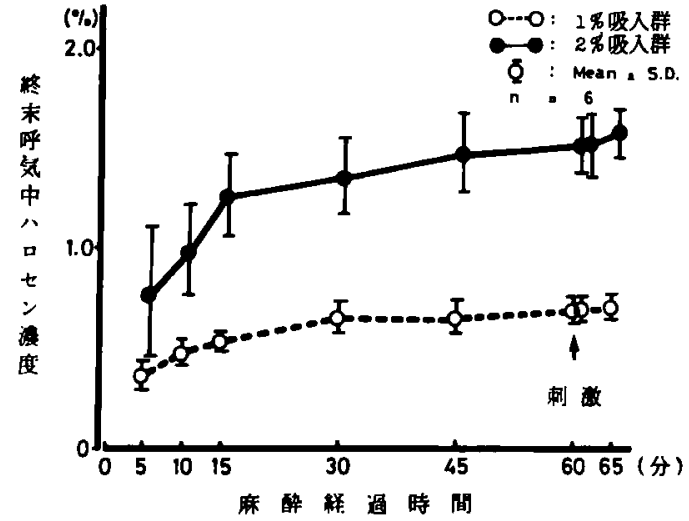

図 3 八ロセン吸入に伴う終末呼気中 八ロセン濃度の経時的変化

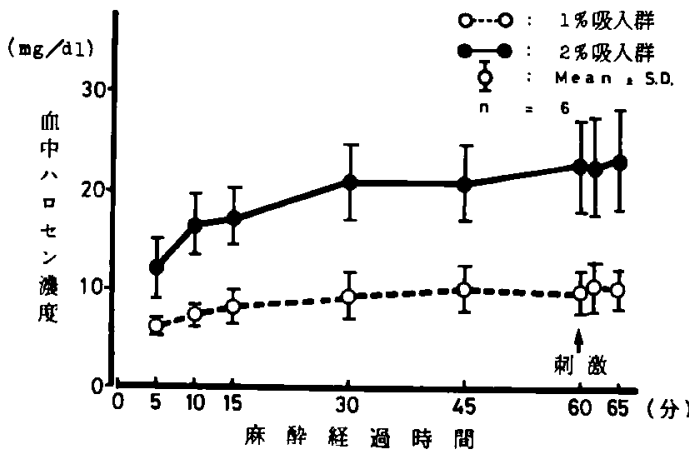

园4 八ロセン吸入に伴う血中八ロセン 濃度の経時的変化 
表 7 ハロセン吸入に伴う血槳エピネフリン䟴度の経時的変化

\begin{tabular}{|c|c|c|c|c|c|c|c|c|c|}
\hline & 対 照 値 & 5 分 & 10 分 & 15 分 & 30 分 & 45 分 & 60 分 & 刺激 30 秒 & 刺激 5 分 \\
\hline 1\% 吸入群 & $\begin{array}{r}237.8 \\
+128.0 \\
\end{array}$ & $\begin{array}{r}201.4 \\
+132.1 \\
\end{array}$ & $\begin{array}{r}179.6 \\
+96.7\end{array}$ & $\begin{array}{r}161.6 \\
+95.5\end{array}$ & $\begin{array}{r}192.8 \\
+\quad 83.3\end{array}$ & $\begin{array}{r}211.4 \\
+110.7\end{array}$ & $\begin{array}{r}211.9 \\
+113.2\end{array}$ & $\begin{array}{r}345.0 \\
+\quad 67.2\end{array}$ & $\begin{array}{r}331.5 \\
+\quad 64.3\end{array}$ \\
\hline 2\%吸入群 & $\begin{array}{r}328.1 \\
+115.2\end{array}$ & $\begin{array}{r}204.5 \\
+164.0\end{array}$ & $\begin{array}{r}203.0 \\
+122.5\end{array}$ & $\begin{array}{r}176.3^{\star} \\
\pm 99.2\end{array}$ & $\begin{array}{r}102.8 \\
\pm 33.9\end{array}$ & $\begin{aligned} & 88.6^{\text {th }} \\
\pm & 39.1\end{aligned}$ & $\begin{array}{r}68.5^{\text {th }} \\
+22.0\end{array}$ & $\begin{array}{r}73.2 \\
+\quad 24.4 \\
\end{array}$ & $\begin{array}{r}70.0^{\text {th }} \\
+18.8\end{array}$ \\
\hline
\end{tabular}

西群ともに $n=6$, 単位 $: p g / m l$ plasma, Mean $\pm S D$,

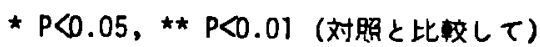

表 8 八ロセン吸入に伴う血漿ノルエピネフリン濃度の経時的変化

\begin{tabular}{|c|r|r|r|r|r|r|r|r|r|}
\hline & 対照檤 & 5 分 & 10 分 & 15 分 & 30 分 & 45 分 & 60 分 & 剌激 30 秒 & 刺激 5 分 \\
\hline $1 \%$ 吸入群 & $\begin{array}{r}201.9 \\
\pm 69.5\end{array}$ & $\begin{array}{r}252.9 \\
\pm 91.1\end{array}$ & $\begin{array}{r}203.1 \\
\pm 81.3\end{array}$ & $\begin{array}{r}189.0 \\
\pm 89.4\end{array}$ & $\begin{array}{r}147.0 \\
\pm 60.9\end{array}$ & $\begin{array}{r}176.8 \\
\pm 68.0\end{array}$ & $\begin{array}{r}185.0 \\
\pm 114.9\end{array}$ & $\begin{array}{r}212.1 \\
\pm 107.6\end{array}$ & $\begin{array}{r}206.7 \\
\pm 96.6\end{array}$ \\
\hline 28 吸入群 & $\begin{array}{r}228.6 \\
\pm 75.2\end{array}$ & $\begin{array}{r}232.7 \\
\pm 83.5\end{array}$ & $\begin{array}{r}224.5 \\
\pm 87.1\end{array}$ & $\begin{array}{r}182.7 \\
\pm 70.0\end{array}$ & $\begin{array}{r}131.4 \\
\pm 28.3\end{array}$ & $\begin{array}{r}120.6 \\
\pm 18.7\end{array}$ & $\begin{array}{r}126.0 \\
\pm 28.7\end{array}$ & $\begin{array}{r}130.7 \\
\pm 26.9\end{array}$ & $\begin{array}{r}142.0 \\
\pm 47.8\end{array}$ \\
\hline
\end{tabular}

両群ともに $\mathrm{n}=6$ 、单位 :pg/ml plasma, Mean $\pm S D$,

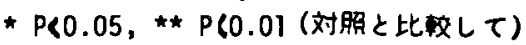

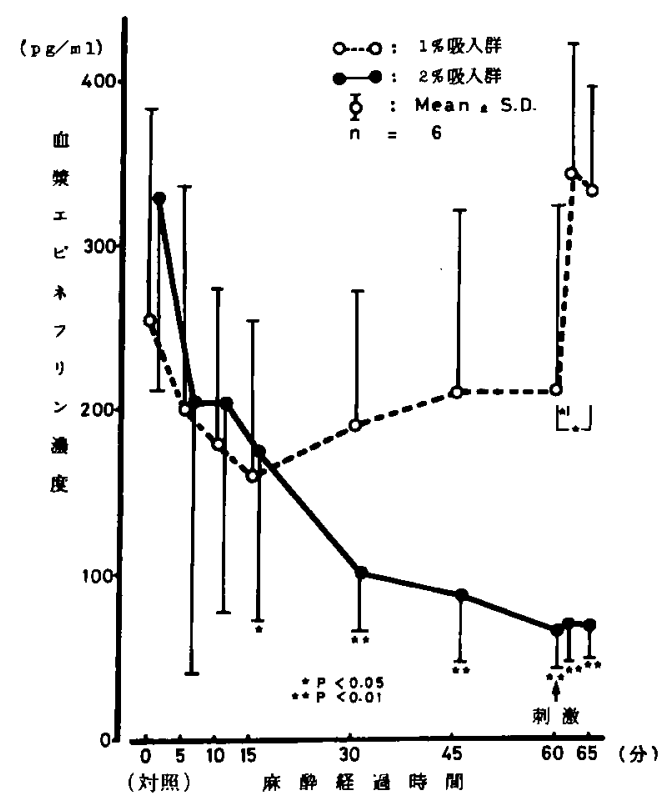

図 5 ハロセン吸入に伴う血獎エピネ フリン濃度の経時的変化

$1 \%$ 吸入群，2\%吸入群ともにハロセン吸入 開始15分後まで急速に増加し，30分以後は，增 加傾向が少なくなり，ほぼ一定濃度となった。

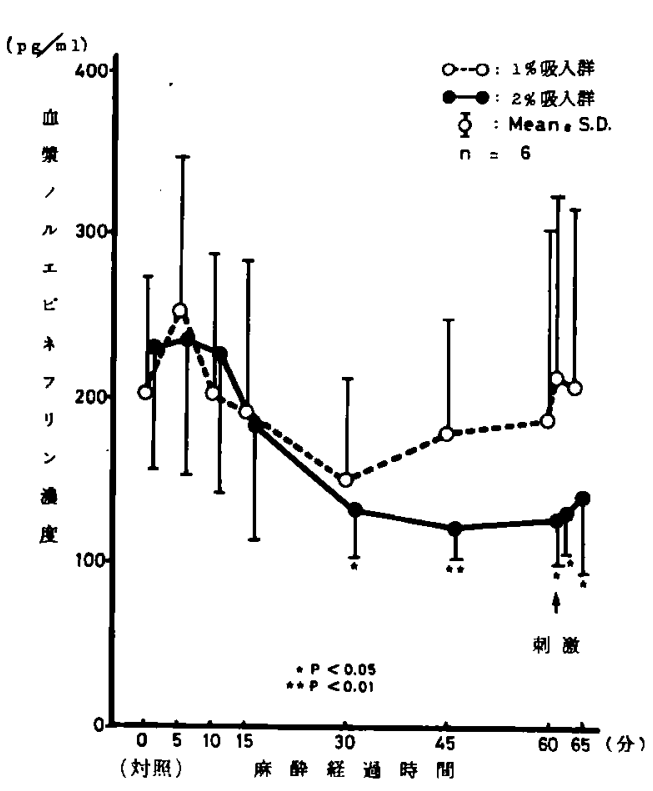

図6 ハロセン吸入に伴う血獎ノルエピネ フリン濃度の経時的変化

また， $1 \%$ 吸入群と $2 \%$ 吸入群とを比較する と, $2 \%$ 吸入群の方が，八ロセン吸入開始 5 分 後から血中八ロセン濃度の有意 $(\mathrm{p}<0.01)$ の增 
加が認められた。

血漿エピネフリン $(\mathrm{E})$ 濃度：血槳 $\mathrm{E}$ 濃度は， 表 7, 図 5 のごとくであった.

$1 \%$ 吸入群における血漿 $\mathrm{E}$ 濃度は, 对照と比 較して，八ロセン吸入開始15分後までは減少傾 向が認められ, その後, 60分後まではやや増加 傾向が認められたが, 有意 $(\mathrm{p}<0.05)$ の差はな かった。しかし、刺激30秒後, 刺激 5 分後は, 八ロセン吸入開始60分後と比較して有意 $(\mathrm{p}<$ 0.05）に增加した。

$2 \%$ 吸入群における血漿 $\mathrm{E}$ 濃度は, 对照と比 較してハロセン吸入開始 15 分後は, $\mathrm{p}<0.05 て ゙$, 30 分以後は, $\mathrm{p}<0.01$ で有意に減少した。

また，1\%吸入群と $2 \%$ 吸入群のそれぞれの 血槳 $\mathrm{E}$ 濃度を比較すると，2\%吸入群の方が, 八ロセン吸入開始 30 分，45分および60分後は， $\mathrm{p}<0.05$ で，刺激 30 秒後および刺激 5 分後は, $\mathrm{p}<0.01$ で有意に減少した。

血漿ノルエピネフリン $(\mathrm{NE})$ 濃度：血漿 $\mathrm{NE}$ 濃度は，表 8 ，図6のごとくであった．

$1 \%$ 吸入群における血漿 $\mathrm{NE}$ 溇度は，对照と 比較してハロセン吸入開始 5 分後にはやや增加 し，その後，30分後までは減少し，45分以後は， 增加の傾向が認められたが, 有意 $(\mathrm{p}<0.05)$ の 差はなかった。八ロセン吸入開始60分後と刺激 30 秒後，刺激 5 分後を比較すると，增加傾向は あるが，有意の差（p<0.05）はなかった。

$2 \%$ 吸入群における血漿 NE 濃度は，八口七 二吸入開始 30 分, 45 分後は, $\mathrm{p}<0.01$ で, 60 分後, 刺激 30 秒後および刺激 5 分後は, $\mathrm{p}<0.05$ で有 意に減少した。刺激 30 秒後，刺激 5 分後は，八 口セン吸入開始60分後よりわずかに增加傾向が うかがわれるが, 有意 $(\mathrm{p}<0.05)$ の差は認めら れなかった。

$1 \%$ 吸入群と $2 \%$ 吸入群のそれぞれの血漿 NE 濃度を比較すると，八ロセン吸入開始 30 分後よ り $2 \%$ 吸入群が, $1 \%$ 吸入群より平均值は低值 にあるが, 有意（ $\mathrm{p}<0.05 ）$ の差はなかった。

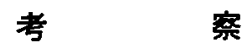

エピネフリン (E) は，春髄に細胞体がある 交感神経節前ニューロンの直接支配を受ける副 腎䯣質のクロム親性細胞で産生され，E眝蔵小
胞に賍蔵され交感神経の刺激により放出される といわれている1)。ノルエピネフリン（NE）は， 交感神経終末の NE 貯藏小胞内と副腎鹃質のク 口ム親性細胞内の貯蔵小胞内にあり，ここから 神経細胞内人拡散し放出されているといわれて いる1)。しかし， NEは，刺激がなくともたえず 神経細胞内に拡散し，微量の NEはたえず漏出 しているといわれている15)。八ロセンは，NEの 漏出には影響しないともいわれている年．また, カテコラミン (CA) の放出を調節するシナプ 又前受容体等種々の機構に対する麻醉薬の影響 について不明の点が多い17).

以前は，八ロセン麻醉時の血淼 $\mathrm{CA}$ 濃度は変 化がないと報告18-21)されていたが，最近は，微 量な血漿 CA 濃度まで測定可能となり，八ロセ ンは，CAの放出を抑制し，血漿 $\mathrm{CA}$ 濃度を減 少すると報告5-10)されている。

血漿 CA 濃度を測定する場合, 試料の前処理, 測定方法は各施設によって異っており22 26), 本研 究では, 試料の前処理として著者の考案した他 の方法より簡便で回収率の高い方法を用いた。 血漿 CA 濃度の測定方法は, 高速液体クロマト グラフを用いた THI 法により行った。また。血中 八ロセン濃度の測定は，種々の方法 ${ }^{27-32}$ がある が, 簡便で信頼度の高い山田ら ${ }^{11} の$ 方法を用い た.

八ロセン $1 \%$ 吸入群と $2 \%$ 吸入群における終 末呼気中と血中における八ロセン濃度は，表 5， 6 , 図 3，4のごとく，八ロセン吸入開始から 30分後まで増加し, その後は, 増加傾向が少な くなった。このことは，八ロセン吸入によりハ ロセン自身が, 肺胞から血中へ, さらに組織へ 吸入および拡散される過程 ${ }^{33)}$ が飽和し, 平衡状 態になるのに約 30 分間を必要とすることが明ら かになった，すなわち，八ロセン吸入開始から 約30分後には，八ロセンの生体への取り込みと 排泄が，一定の状態になるものと考えられる。 血圧と心拍数についてみると，八ロセンは， 循環器系の抑制があるといわれている34)が，本 研究においては, 表 3 のごとく血圧は，1\%吸 入群, $2 \%$ 吸入群ともに八ロセン吸入開始 5 分 後から对照にくらべ有意に減少し，30分後から， すなわち，血中および組織内への八ロセンの取 
り込み，排泄が平衡状態になった時点からは， 減少した状態でほぼ一定となった。また，1\% 吸入群より $2 \%$ 吸入群の方が，低值を示し，八 ロセン吸入開始45分以後は, 有意に減少した. 心拍数は，八ロセン吸入開始 5 分後に，1\%吸 入群，2\%吸入群ともにやや一過性に增加した がそその後は減少した。しかし、两群の間に有 意の差は認められなかった。以上のことより， 八ロセンによる心拍出量の減少35や全末梢血管 抵抗の滅少 ${ }^{31}$ が，血中八ロセン濃度が濃いほど 大きくなると考えられる。

血漿 $\mathrm{CA}$ 濃度に関しては, 血漿 $\mathrm{E}$ 濃度の動態 は，表 7, 図 5 のごとくで，1\%吸入群は，八 口セン吸入開始15分後までは, 減少傾向を示す が, 30分後から60分後までは，やや增加傾向が あり，对照と比較してすへてての時点で有意の差 は認められなかった。 $2 \%$ 吸入群では，八ロセ ン吸入開始 5 分後より減少し, 15分後から60分 後までは，対照と比較して有意に減少した。ま た， $1 \%$ 吸入群と $2 \%$ 吸入群を比較すると， 30 分後から60分後までは， $2 \%$ 吸入群の方が有意 に減少した．以上のことから，1\%吸入群すな わち血中八ロセン濃度が, 約 $10 \mathrm{mg} / \mathrm{dl}$ 以下の場 合は，副腎髄質からのEの放出に对して影響が 少ないため, 血漿 $\mathrm{E}$ 濃度は, 対照と比較して差が なかった。しかしし，2\%吸入群で血中ハロセン 濃度が, 約 $20 \mathrm{mg} / \mathrm{dl}$ 以上の場合は, 副腎咀質よ りの $\mathrm{E} の$ 放出が抑制されたため，血漿 $\mathrm{E}$ 漕度は， 対照と比較して有意に減少した。 $1 \%$ 吸入群と 比較しても八ロセン吸入開始 30 分以後は，有意 の差が認められた。

電気刺激を与えた場合の血槳 $\mathrm{E}$ 濃度の動態に ついてみると，1\%吸入群では，八ロセン吸入 開始60分後に比較して, 刺激 30 秒後, 刺激 5 分 後ともに血漿 $\mathrm{E}$ 濃度が, 有意に增加したことが 認められた。しかし，2\%吸入群は，刺激30秒 後, 刺激 5 分後ともに，八口セン吸入開始60分 後に比較して差は認められなかった１％吸入 群と $2 \%$ 吸入群を比較すると, 刺激 30 秒後, 刺 激 5 分後ともに有意の差が認められた。このこ とは；電気刺激による交感神経系の反応により 副腎髄質が刺激され，Eが眝藏小胞から放出さ れる機構が, 血中八ロセン濃度が, 約 $20 \mathrm{mg} / \mathrm{dl}$
以上になると抑制されることが確められた。

以上より，八ロセンは，血中八ロセン濃度か， 約 $20 \mathrm{mg} / \mathrm{dl}$ になると副腎㵦質からの $\mathrm{E}$ の放出を 抑制することが明らかとなった。このことは, 八ロセンによる交感神経系の反応の抑制は考之 られるが, 血中八ロセン濃度が濃くなると，心 拍出量の減少 ${ }^{35)}$ ，全末梢血管抵抗の減少 ${ }^{33}$ に上 $\eta$ 副腎髄質の機能が低下し， $\mathrm{E} の$ 放出が抑制さ れることも考えられる。

血漿 NE 濃度の動態は, 表 8 , 図 6 のごとく で， $1 \%$ 吸入群は，八ロセン吸入開始 5 分後に 一過性にやや增加するが, 30分後までは減少傾 向があり，その後60分後までやや增加傾向があ るものの対照と比較して，ぞの時点でも有意の 差は認められなかった，2\%吸入群でも，八口 セン吸入開始 5 分後は，やや增加するが，その 後60分後まで減少し, 30 分後からは, 対照と比 較して有意に減少した． $1 \%$ 吸入群が，対照と 比較してどの時点でも有意の差がなかったこと は，血獎 $\mathrm{E}$ 濃度，動態同様に，血中八口セン濃 度が, 約 $10 \mathrm{mg} / \mathrm{d} 1$ 以下では, NE の交感神経終 末や副腎髄質からの放出に对してハロセン麻醉 の影響が少ないことが明らかとなった。 $2 \%$ 吸 入群では, 八ロセン吸入開始30分後からは，対 照と比較して血漿 NE 濃度は，有意に減少した。 しかし，1\%吸入群と比較すると有意の差は認 められなかったが, 減少傾向がみられた。この ことは，血中ハロセン濃度が，約 $20 \mathrm{mg} / \mathrm{dl}$ 以上 になると NEの放出が，八ロセン麻醉により抑 制される傾向にあるものと思われる。

八ロセン吸入開始 5 分後の血漿 $\mathrm{NE}$ 濃度の增 加傾向は，八ロセン吸入直後の八ロセン自身の 刺激36によるものと思われる。

電気刺激を与之た場合の血漿 $\mathrm{NE}$ 濃度の動態 をみると，1\%吸入群の方が $2 \%$ 吸入群と比較 して, やや增加しているようであるが, 両群と もに八ロセン吸入開始60分後と比較して, 刺激 30秒後, 刺激 5 分後ともに有意の差を認めなか った. しかし，60分後からの個々の增加率の平 均では，1\%吸入群は，刺激30秒後が， $21.2 \%$, 刺激 5 分後が，20.1\%で，2\%吸入群では，そ れぞれ4.6\%，11.9\%であった。したがって， $2 \%$ 吸入群, すなわち血中八ロセン濃度が約 20 
$\mathrm{mg} / \mathrm{dl}$ 以上では， $1 \%$ 吸入群，すなわち血中八 ロセン濃度が約 $10 \mathrm{mg} / \mathrm{dl}$ 以下より,電気刺激に 対して血中へのノルエピネフリンの放出抑制が 強いことが, 平均増加率の上から考えられる。

八ロセンの NEに対方る影響は, 放出機構へ の作用点や，NE 自身の代謝への作用などいま だ解明されていないのが現況であるが，本研究 においては，血中ハロセン濃度が約 $20 \mathrm{mg} / \mathrm{dl}$ 以 上になると，交感神経終末からあるいは副腎髄 質からの NEの放出機構のいずれかを抑制し, 血獎 NE 濃度が減少すると考之られる。

また，血中八ロセン濃度が，約 $20 \mathrm{mg} / \mathrm{dl}$ 以上 と, 約 $10 \mathrm{mg} / \mathrm{dl}$ 以下とを比較すると, 血圧下降 は有意の差があった。このことは，前述したよ うに, 血中八ロセン濃度が約 $20 \mathrm{mg} / \mathrm{dl}$ 以上にな ると，血槳 NE 濃度を減少させるだけでなく， 八ロセン自身が，心筋自体に作用し，心収縮力 の減少から心拍出量の減少, さらに血管に作用 し拡張させて血圧を減少さす16)ことも考之られる。 以上，八ロセン麻酔中の血獎 CA 濃度を測定 したが，八ロセン麻酔の臨床においては，血漿 $\mathrm{CA}$ 濃度が, 血中八ロセン濃度の変化に相関し て変動していること, 交感神経系の反応が, 血 中八ロセン濃度が約 $20 \mathrm{mg} / \mathrm{dl}$ 以上になると, 明 らかに抑制されることを考慮し，生体に対し安 全な麻酔を行なうように心掛けなければならない。

\section{結語}

本研究は，八ロセン吸入開始から60分後まで, さらに電気刺激を行って 30 秒後と 5 分後の血中 八ロセン濃度と血槳カテコラミン濃度をガスク ロマトグラフと高速液体クロマトグラフを用い て，測定し，両者の相関関係を検討した。

$1 \%$ 吸入群，2\%吸入群ともに終末呼気中お 上び血中八ロセン濃度は, 八ロセン吸入開始約 30 分後まで増加し，その後は，血中および組織
への取り込みと排泄が、それぞれ平衡状態とな り，一定となった。 $1 \%$ 吸入群に比較して $2 \%$ 吸入群の方が，八ロセン吸入開始 5 分後より終 末呼気中および血中ハロセン濃度ともに有意に 増加した。

血圧は，1\%吸入群，2\%吸入群ともにハ口 セン吸入開始 5 分後より対照と比較して有意に 減少し，45分後すなわち血中八口セン濃度が， 約 $10 \mathrm{mg} / \mathrm{dl}(1 \%$ 吸入群）と約 $20 \mathrm{mg} / \mathrm{dl}(2 \%$ 吸入群）の時点で $2 \%$ 吸入群の方が有意に減少 した。 心拍数は，1\%吸入群は，八ロセン吸入 開始 30 分後， $2 \%$ 吸入群は，45分後より対照と 比較して有意に減少したが, 両群間に有意の差 は認められなかった。

血槳エピネフリン濃度は，血中八ロセン濃度 が，約 $20 \mathrm{mg} / \mathrm{dl}$ 以上になると有意に減少し，電 気刺激によっても血漿エピネフリン濃度の増加 は認められなかった。しかし，血中八ロセン濃 度が約 $10 \mathrm{mg} / \mathrm{dl}$ 以下では電気刺激に対して, 血 墏エピネフリン濃度は明らかに有意に增加した。

血漿ノルエピネフリン濃度は, 血中八ロセン 濃度が約 $10 \mathrm{mg} / \mathrm{dl}$ 以下では変化がなかったが, 約 $20 \mathrm{mg} / \mathrm{dl}$ 以上では对照と比較して有意に減少 した。

以上より，血中八ロセン濃度が約 $20 \mathrm{mg} / \mathrm{dl}$ 以 上においては，八ロセンは，交感神経系の反応 を抑制し，血中へのカテコラミンの放出を抑制 することが, 確認された。

稿を終えるにあたり，御瑟篤なる御指導，御校閲 を賜った岡山大学歯学部西嶋克已教授ならびに医学 部麻酔学教室小坂二度見教授に心よりの感謝を捧げ るとともに，同教室山田輝夫博士，板野義太郎助手 はじめ教室各位に謝意を表します。

本論文の要旨は, 第 31 回日本麻醉学会 (昭和 59 年 4 月, 福岡）にて発表した。

\section{女献}

1. 高垣玄吉郎：伝達物質としてのカテコールアミンとその代謝調節。神経生化学 I ，共立出版, 東京, pp. 166-219, 1981.

2. 宮崎正夫 : Adrenergic and Anti-adrenergic agents 臨床麻醉学書上巻, 山村秀夫編, 金原出版, 東京, pp 621-645, 1979. 
3. Axelrod, J. and Weinshilboum, R.: Catecholamines. Engl. J. Med. 287, 237-242, 1972.

4. 三浦幸雄, 富岡 洋: 心臓交感神経機能評価の指標としての血槳カテュールアミン濃度について。呼と循, 28, 1111-1117, 1981.

5. Perry, L.B., Van Dyke, R.A. and Theye, R.A.: Sympathoadrenal and hemodynamic effects of isoflurane, halothane, cyclopropane in dogs. Anesthesiology 40, 465-470, 1974.

6. Roizen, M.F., Moss, J., Henry, D.P. and Kopin, I.J.: Effects of halothane on plasma catecholamines. Anesthesiology 41, 432-439, 1974.

7. Gangat, Y., Vulliemoz, Y., Verosky, M., Danilo, P., Bernstein, K. and Triner, L.: Action of halothane on myocardial adenylate cyclase of rat and cat. Proc. Soc. Exp. Biol. Med. 160, 154-159, 1979.

8. Balasaraswathi, K., Glisson, S.N., El-Etr, A.A. and Azad, C.: Effect of priming volume on serum catecholamines during cardiopulmonary bypass. Canad. Anaesth. Soc. J. 27, 135-139, 1980.

9. Hoar, P.F., Stone, J.G., Faltas, A.N., Bendixen, H.H., Head, R.J. and Berkowitz, B.A.: Hemodynamic and adrenergic responses to anesthesia and operation for myocardial revascularization. $J$. Thorac. Cardiovasc. Surg. 80, 242-248, 1980.

10. Brismar, B., Hedenstierna, G., Lundh, R. and Tokicks, L.: Oxygen uptake, plasma catecholamines and cardiac output during neurolept-nitrous oxide and halothane anesthesia. Acta Anesth. Scand. 26, $541-549,1982$.

11. 山田輝夫, 西本雅彦, 瀬戸甲蔵, 飯島義雄, 板野義太郎, 木村重雄, 武田明雄, 平川方久, 小坂二度見 : ガスクロマトグラフによる血中麻醉薬濃度の測定に関する研究(I)一血中八ロセン濃度の直接測定法の改良 一。麻酔, 31, 36-44, 1982 .

12. Lund, A.: Fluorimetric determination of adrenaline in blood. III. A new sesitive and specific method. Acta Pharmacol. 5, 231-247, 1949.

13. 森田恭二, 岡 源郎, 永津俊治, 泉 太：カテコールアミン. 生化学実験講座11, 日本生化学会編, 東京 化学同人, pp. 725-770, 1977.

14. 扇谷茂樹, 初田和由, 久城英人, 归玉順三, 岸本康朗, 田中一彦：血中カテコールアミン測定の簡易前処 理法. 臨床病理, 30, 1251-1254, 1982.

15. Verbeuren, T.J. and Vanhoutte, P.M.: Influence of MAO-inhibitors on deamination of ${ }^{3} \mathrm{H}$-norepinephrine in the dog's saphenous vein. Arch. Int. Pharmacodyn. 232, 348-349, 1978.

16. Muldoon, S.M., Vanhoutte, P.M. and Lorenz, R.R. and Van Dyke, R.A.: Venomotor changes caused by halothane acting on the sympathetic nerves. Anesthesiology 43, 41-48, 1975.

17. 福田 悟, 武下 浩：麻酔と血管平滑筋。臨床麻酔, 8, 5-15, 1984.

18. Price, H.L., Linde, H.W., Jones, R.E., Black, G.W. and Price, M.L.: Sympatho-adrenal responses to general anesthesia in man and their relation to hemodynamics. Anesthesiology 20, 563-575, 1959.

19. Hemelberg, W., Sprouse, J.H., Mahaffey, J.E. and Richardson, J.A.: Catechol amine levels during light and deep anesthesia. Anesthesiology 21, 279-301, 1960.

20. Millar, R.A. and Morris, M.E.: Sympatho-adrenal responses during general anesthesia in the dog and man. Can. Anaes. Soc. J. 8, 356-386, 1961.

21. Dobkin, A.B., Byles, P.H. and Neville, J.F.: Neuroendocrine and metabolic effects of general anesthesia during spontaneous breathing, controlled breathing, mild hypoxia, and mild hypercarbia. Can. Anaes. Soc. J. 13, 130-171, 1966.

22. 市村孝道：カテコールアミンおよびインドールアミンの GC/MS. 森 昭片編, 神経伝達物質測定法マ二 ュアル, 医歯菌出版, 東京, pp. 70-80, 1979. 
23. 中井利昭, 山田律爾：血中カテコラミン測定用 CAT-A-KITについての検討拈よび健常成人の血中カテコ ラミン動態について。臨床病理，28，915一-919，1980。

24. 加藤 武, 越谷和雄, 永津俊治 : 体液中カテコールアミンの高速液体クロマトグラフィー一電気化学検出 器に上る分析。蛋白質，核酸，醳素，26，1129-1134，1981.

25. 菊池 元, 山崎陽之介, 滝口 守, 中村武志, 䔩田ゆき, 加藤秀一, 天野道之助, 山本正博：小児顔面 形成手術におけるハロセン麻醉とエピネフリン添加リドカイン局注併用による血圧, 心電図および血中カ テコラミン洤度の変化. 麻醉, 31, 825-829, 1982.

26. 丸川愛子：肺内因性カテコラミンに及ぼす低酸素症の影響について。麻酔，32，394-401，1983.

27. Noehren, T.H. and Cudmore, J.W.: Ethyl ethyr content in blood as determined by gas chromatography. Anesthesiology 22, 519-524, 1961.

28. Dyfverman, A. and Sjövall, J.: Estimation of fluothane by gas chromatography. Acta Anaesth. Scand. 6, 171-174, 1962.

29. Chambliss, K.W. and Nouse, D.C.: Blood oxygen determination by gas chromatography. Clin. Chem. 8, 654-659, 1962.

30. 若杉文吉：機器によるガス分析一麻醉がスと血中がス一，麻酔，12，778一787，1963.

31. Fink, B.R. and Morikawa, K.: A simplified method for the measurement of volatile anesthetics in blood by gas chromatography. Anesthesiology 32, 451-455, 1970

32. Cromwell, T.H., Eger, E.I., Stevenson, W.C. and Dolan, W.M.: Forane uptake excretion, and blood solubility in man. Anesthesiology 35, 401-408, 1971.

33. 斉藤公男，鈴木美保子，奥秋 戟，伊関信子：ガスクロマトグラフィー,内部標準法による血中エーテル， フローセン, ペントレンの直接測定について。麻醉，24，332-337，1975.

34. 山村秀夫：吸入麻酔剤。臨床麻醉学書上巻, 山村秀夫編, 東京, pp. 539-560， 1979 .

35. Merin, R.G.: Efeect of anesthetics on the heat. Surg. Clin. N. Am. 55, 759-774, 1975.

36. Joyce, J.T., Roizen, M.F., Gerson, J.I., Grobecker, H., Egerll, E.I. and Forbes, A.R.: Induction of anesthesia with halothane increases plasma norepinephrine concentrations. Anesthesiology 56, 286 $-290,1982$. 


\title{
Plasma Catecholamine Concentration During Halothane Anesthesia
}

\author{
Hisatake YAO
}

\author{
First Department of Oral Surgery, Dental School, Okayama University
}

(Director: Prof. K. Nishijima)

\begin{abstract}
Almost all of the norepinephrine as a neurotransmitter is released from and reincorporated into sympathetis nerve endings, except for some which escapes into the blood. Pursuant to the activity of the sympathetic nervous system, the adrenal medulla secretes both norepinephrine and epinephrine into the blood. Thus, the plasma catecholamine concentration is an index of sympathetic nervous system activity.

Halothane is said to decrease the plasma catecholamine concentration, but there have been no reports concerning the mutual relationship between the halothane and catecholamine levels. In the present study, the blood halothane and plasma catecholamine concentrations were measured within 60 minutes of $1 \%$ and $2 \%$ halothane inhalation, and 30 seconds and 5 minutes after an electric stimulation following 60 minutes of inhalation.

The blood halothane concentration increased up to 30 minutes after the beginning of halothane inhalation and leveled off thereafter in both the $1 \%$ and $2 \%$ inhalation groups. Thirty minutes after the beginning of inhalation, the blood halothane concentration was significantly higher in the $2 \%$ inhalation group $(20 \mathrm{mg} / \mathrm{dl}$ blood) than in the $1 \%$ inhalation group $(10 \mathrm{mg} / \mathrm{dl}$ blood).

The plasma epinephrine concentration was not significantly different between the $1 \%$ inhalation group and the control up to 60 minutes of inhalation. However, 30 seconds and 5 minutes after an electric stimulation following 60 minutes of inhalation, the epinephrine level increased significantly. In the $2 \%$ inhalation group, the epinephrine level decreased significantly below the control level 15 minutes after the inhalation was started, and from 30 minutes the level was even significantly lower than that of the $1 \%$ inhalation group.

The blood norepinephrine concentration was not significantly different between the $10 \%$ inhalation group and the control up to 60 minutes of inhalation, but was significantly lower in the $2 \%$ inhalation group than the control after 30 minutes of inhalation. The norepinephrine level increased slightly in both groups after an electric stimulation, but not significantly above the respective level at 60 minutes.

These results indicate that when the blood halothane concentration rises above 20 $\mathrm{mg} / \mathrm{dl}$, the catecholamine release, and the sympathetic nervous system response, are suppressed.
\end{abstract}

